INCREASED RESISTANCE TO PNEUMOCOCCAL INFECTION IN FEMALE RATS AND DIETHYLSTILBESTEROL TREATED MALES. Robert H. Drachman,

Dept. of Ped., Johns Hopkins Univ. School of Med., Baltimore.

Female rats and males treated with diethylstilbesterol (DES) were more resistant to $i . v$. pneumococcal challenge than were untreated males. These observations may parallel the clinical findings.

The i.v. LD 50 in male rats for Pneumococcus Type 25 (Pn25) is $5 \times 10^{5}$ viable organisms. Challenge of female rats with this $\mathrm{LD}_{50}$ dose of the Pn25 resulted in a significantly lower mortality. Splenectomized male and female rats were challenged $i . v$. with the same numbers of viable pneumococci. All males died, while about one-half of the females survived. DES was given s.c., 0.5 to $1 \mathrm{mg}$ pex day for 5 days to male rats weighing about $200 \mathrm{gm}$, while similar control rats received cotton seed oil only, the vehicle for the DES. Body weight decreased about $35 \mathrm{gm}$ by day 6 . On day 8 DES treated males and controls were challenged $i . v$. with the $\mathrm{LD}_{50}$ dose of Pn25. Mortality in the DES treated males was comparable to that in females and was significantly different from mortality in cotton seed oil treated control males. In vitro phagocytic studies using the Pn25 as the test particle and two-way combinations of DES treated and normal cells and serum failed to reveal differences in cellular phagocytic activity or levels of serum opsonizing activity. In vivo DES was capable of producing changes in male rats which caused them to resemble females in their resistance to $i . v$. pneumococcal challenge.

\section{COMPLEMENT-MEDIATED HISTAMINE RELEASE FROM HUMAN} LEUKOCYTES. El ton Dupree, Armond S. Goldman and J. Andrew Grant, Dept. of Pediatrics and Internal Medicine, University of Texas Medical Branch and Shriners Burns Institute, Galveston, Texas.

$\mathrm{C} 3 \mathrm{a}$ and $\mathrm{C} 5 \mathrm{a}$, products of complement (C) activation, produce histamine release (HR) from guinea pig mast cells and cause mast cell degranulation when injected into human skin. Since complementmediated histamine release from human blood leukocytes has not been demonstrated, the present study was undertaken.

The alternate pathway of $C$ was activated by incubating fresh human serum with zymosan. HR from autologous leukocytes was assayed fluorometrically. In 16 normal non-atopic donors $45 \% \pm 10 \%$ (mean \pm SD) of intracellular histamine was released from leukocytes incubated with zymosan-activated serum. Evidence that $\mathrm{C} 3 a$ and $\mathrm{C} 5 \mathrm{a}$ were generated included the following: I)chemotaxis of PMN's was demonstrated after zymosan treatment of serum, and 2)HR was prevented by heating the serum at $56^{\circ} \mathrm{C}$ or by absorption with anti-C3 or anti-C 5 . HR was also inhibited by incubating leukocytes in the cold, by pretreating leukocytes with theophylline or EDTA. When the classic pathway of $C$ was activated by incubating serum with BSA-anti-BSA complexes, $H R$ was similar to that obtained with zymosan.

This study indicates that activation of the altemate or classic pathway of $C$ causes HR from human leukocytes. It seems likely that this pathway is an important mechanism for the release of chemical mediators of inflammation in certain immunopathologic diseases.

FACILITATION OF ANTIGENIC LEUKOCYTE HISTAMINE RELEASE BY A SOLUBLE FACTOR. Peyton A. Eggleston and Angela W. Eggleston, Depts. of Ped. and Med., (Intr. by Diane M. Komp), Univ. of Virginia, Charlottesville.

Basophils from certain allergic subjects will secrete histamine when exposed to appropriate antigens; after repeated washings this reactivity is lost. To examine the possibility that washing removes a membrane-bound factor other than IgE necessary for antigenic histamine release, allogeneic unreactive cells from allergic donors were exposed to washes from reactive cells then challenged with antigen. Histamine release was measured by the usual methods (J.E.M. 120: 507, 1964). Reactive leukocytes were separated in Dextran, washed twice in Tris BSA buffer $(\mathrm{pH} \mathrm{7.4)}$ and the washes saved. Unreactive cells were similarly separated, washed, then incubated in Tris BSA buffers with added $\mathrm{Ca}^{++}$and $\mathrm{Mg}^{++}$for one hour at $37^{\circ} \mathrm{C}$., then resuspended with fresh Tris $\mathrm{BSA} \mathrm{Ca}{ }^{++}$and $\mathrm{Mg}^{++}$buf fer for ragweed antigen challenge. Washes from two or four reactive donors were capable of inducing non-reactive cells to release $62-100 \%$ total histamine on antigen challenge; no more than $10 \%$ total histamine was released from incubated cells not exposed to antigen. Allogeneic cells from normal non-allergic donors could not be induced to release histamine. The facilitating ability of the washes was not destroyed at $56^{\circ} \mathrm{C}$. for one hour and was non-dializable. We concluded that leukocytes capable of antigenic histamine release have a protein on their surface which is not IgE and which is necessary for antigenic histamine release.
DISSOCIATED LYMPHOCYTE FUNCTION IN NEWBORN INFANTS. R. Eife, G. Eife, K. Staehr-Johansen and C. August. (Intr. by W. Hathaway). Univ. of Colo. Med. Ctr., Dept. of Pediatrics, Denver. The correlation between phytohemagglutinin (PHA) induced blast cell transformation (BCT) and production of lymphotoxin (LT), a cytotoxic mediator of cellular immunity, was studied in the cord blood lymphocytes of 17 normal newborns. Twelve normal adults served as controls. BCT was estimated as uptake of 3-H-thymidine, and LT as the percent inhibition of DNA synthesis of growing target cells.

$B C T$ by newborn lymphocytes was slightly greater than that of adults. By contrast, LT production by the newborns was only $40 \%$ that of the adults. Calculation of an "LT Index" (ratio of LT production to $B C T$ ) revealed that for any degree of BCT, newborn lymphocytes produced only one-fourth as much LT as did adult cells. In 6 infants, the percent of lymphocytes forming rosettes with sheep red cells ( $T$-cell rosettes) averaged $80 \%$ (range $63-90 \%$ ), which is comparable to that of adults.

The combination of impaired mediator production with normal BCT represents a dissociation of lymphocyte function which appears to be a stage in the normal maturation of cellular immune competence. This may, in part, explain the undue susceptibility of newborn infants to certain mycobacterial, fungal and viral infections.

THE UPTAKE OF 125 I - LABELLED RAT ALLOANTIBODY AND ITS LOSS AFTER COMBINATION WITH ANTIGEN. Richard N. Fine, J. Richard Batchelor, Michael E. French and Kenneth Shumak. McIndoe Memorial Research Unit, Queen Victoria Hospital, Sussex, England, Department of Pediatrics, University of Southern California School of Medicine and Dialysis and Transplant Program, Childrens Hospital of Los Angeles.

1251 - Tabelled transplantation al loantibody was injected into long surviving, enhanced and recently transplanted, nonenhanced kidney grafts. Both types of grafts bound the same amount of specific antibody and subsequently released it at a similar rate indicating a dynamic state of antigen turnover by renal allografts and an undiminished number of free antigen sites in long surviving enhanced grafts. In vitro studies showed that 1251 - labelled alloant ibody which combined specifically with target cells exhibited similar phenomenon as grafts in vivo. After 15-18 hours of incubation, 27.5-55.8\% of bound label was shed from target cells into surrounding medium and serial elution studies showed that after 183 hours of incubation in vitro $>90 \%$ of counts specifically attached were shed. The released labelled material contained little specific reactivity indicating that either released antibody was aggregated or degraded, the radiolabel had been stripped from the antibody molecule or the antibody had been released combined with antigen i.e. complex. Subsequent studies utilizing gel filtration and radioimmunoassay were employed in at tempts to characterize released material.

ENHANCED HOST DEFENSE MECHANISM WITH PHENYL-IMIDOTHIOZOLE. Gerald W. Fischer, Vernon T. Oi, Edgar P. Ampaya, James $\mathrm{L}$. Kelley and James $W$. Bass. Dept. of Pediatrics, Tripler Army Medical Center, Honolulu, Hawaii.

Phenyl-imidothiazole (PIT), an immunologic stimulant, was studied in newborn Wistar rats to evaluate its effectiveness in modifying infection induced by challenge with bacterial pathogens. PIT $\left(0.03 \mathrm{mg}\right.$ in $0.03 \mathrm{ml}$ of sterile $\left.\mathrm{H}_{2} 0\right)$ or a placebo ( $0.03 \mathrm{ml}$ sterile $\mathrm{H}_{2} \mathrm{O}$ ) was given (s.c.) on the $2 \mathrm{~d}, 3 \mathrm{~d}$, and 4 th days of life. On the $3 \mathrm{~d}$ day of life Staphylococcus aureus $\left(10^{6} \mathrm{CFU}\right)$ or group A beta hemolytic streptococci $\left(10^{3} \mathrm{CFU}\right)$ was injected (s.c.) at a different site. Survival in animals pretreated with PIT challenged with Staphylococci was 41/45; it was only $3 / 59$ in those with the placebo $(\mathrm{P}=<, 001)$. Survival in animals pretreated with PIT and challenged with Streptococci was $11 / 12$; and $2 / 13$ in those that had received the placebo $(P=<.005) .20$ of 20 PIT controls survived. Delay in PIT administration until challenge on day 3 showed no protection $(2 / 18)$. PIT was not effective in vitro. Nonpretreated animals died with cellulitis of the skin and subcutaneous tissue extending rapidly from the injection site. Pretreated animals thrived while developing a localized subcutaneous abscess which healed leaving a small scar at the injection site. Pretreatment with PIT obviously potentiates the primary inflammatory response providing protection against bacterial challenge in this newborn animal model. It may have some clinical application in management of patients at high risk to bacterial pathogens of this nature. 